\title{
ALAT SABLON UNTUK MENUNJANG TAMPILAN KEMASAN KRUPUK CUMI PADA KELOMPOK USAHA POKLAHSAR MANDIRI BANYUWANGI
}

\author{
Mochamad Asrofi'), Mochammad Edoward Ramadhan ${ }^{1)}$, Sujito ${ }^{2)}$ \\ 1)Jurusan Teknik Mesin, Fakultas Teknik, Universitas Jember, Jalan Kalimantan Kampus Tegalboto, Jember 61261, \\ Jawa Timur, Indonesia \\ ${ }^{2)}$ urusan Fisika, Fakultas Matematika dan IImu Pengetahuan Alam, Universitas Jember, Jalan Kalimantan Kampus Tegalboto, \\ Jember 61261, Jawa Timur, Indonesia \\ Corresponding author : Mochamad Asrofi \\ E-mail : asrofi.teknik@unej.ac.id
}

Diterima 09 November 2020, Direvisi 12 November 2020, Disetujui 12 November 2020

\begin{abstract}
ABSTRAK
Program pengabdian kepada masyarakat bertujuan untuk menyelesaikan permasalahan yang dihadapi oleh mitra pengabdian yaitu kelompok usaha kecil rumahan "Poklahsar Mandiri" yang bergerak di bidang produksi kerupuk cumi. Kelompok usaha ini terletak di Desa Karangsari, Sempu, Banyuwangi. Metode pelaksaan pengabdian ini berupa studi wawancara dan observasi. Wawancara dilakukan berupa diskusi kecil tentang permasalahan kelompok mitra. Permasalahan utama yang dialami oleh mitra ini adalah kemasan plastik yang belum ada labelnya (polos). Kelompok usaha ini menginginkan adanya transfer teknologi yang berupa pembuatan alat sablon kemasan plastik untuk krupuk cumi. Selanjutnya, tim pengabdian melakukan observasi lapang untuk melihat kondisi nyata kelompok usaha ini. Alat sablon kemasan plastik berlabel diharapkan dapat menghasilkan kemasan plastik yang mempunyai daya tarik pembeli. Selain itu, sebagai akibat penjualan meningkat, kesejahteraan kelompok usaha kecil ini dapat terwujud. Sebagai informasi bahwa jumlah produksi kerupuk cumi dari kelompok usaha ini rata-rata per tahunnya $850 \mathrm{~kg}$ per tahunnya (harga per $\mathrm{kg} 40.000$ ). Dengan adanya alat sablon diharapkan ongkos produksi dapat diminimalkan serta penjualan kerupuk cumi meningkat dikarenakan kemasan yang menarik. Hal tersebut diindikasikan peningkatan penjualan kerupuk cumi yang semula $850 \mathrm{~kg}$ menjadi $1000 \mathrm{~kg}$ per tahunnya.
\end{abstract}

Kata kunci: alat sablon; kemasan plastik; kerupuk cumi; poklahsar mandiri.

\begin{abstract}
The community service program aims to solve the problems faced by community service partners, namely the small home business group "Poklahsar Mandiri" which is engaged in the production of squid crackers. This business group was located in Karangsari Village, Sempu, Banyuwangi. The method of implementing this service is in the form of interview and observation studies. Interviews were conducted in the form of small discussions about the problems of the partner group. The main problem experienced by these partners is plastic packaging that has no label (plain). This business group wants a technology transfer in the form of making screen printing plastic packaging tools for squid crackers. Furthermore, the community service team conducted field observations to see the real condition of this business group. This labeled plastic packaging screen printing tool is expected to produce plastic packaging that has a buyer appeal. In addition, as a result of increased sales, the welfare of this small business group can be realized. For information, the amount of squid cracker production from this business group averages $850 \mathrm{~kg}$ per year (price per $\mathrm{kg} \mathrm{40,000).} \mathrm{With} \mathrm{the} \mathrm{screen} \mathrm{printing} \mathrm{equipment,} \mathrm{it} \mathrm{is} \mathrm{hoped} \mathrm{that} \mathrm{production}$ costs can be minimized and sales of squid crackers will increase due to the attractive packaging. This is indicated by an increase in sales of squid crackers from $850 \mathrm{~kg}$ to $1000 \mathrm{~kg}$ per year.
\end{abstract}

Keywords: screen printing equipment; plastic packaging; squid crackers; poklahsar mandiri.

\section{PENDAHULUAN}

Salah satu kelompok usaha kecil yang berada di Kabupaten Banyuwangi adalah kelompok usaha pembuatan krupuk dari hasil perikanan. Poklahsar Mandiri adalah kelompok usaha kecil yang bergerak pada bidang pembuatan krupuk cumi. Lokasi kelompok usaha ini terletak di Desa Karangsari,
Kecamatan Sempu, Kabupaten Banyuwangi. Kelompok usaha pembuatan krupuk cumi Poklahsar Mandiri ini diketuai oleh Bapak Hamim. Jenis tangkapan ikan cumi yang dibuat olahan kerupuk adalah tangkapan cumi dari daerah Muncar, Banyuwangi.

Kelompok pembuatan krupuk cumi tersebut didirikan tahun 2018. Organisasi ini 
terdiri dari ketua dan anggota. Ketua berperan sebagai pengawas sekaligus menjadi pengatur dari anggota yang bekerja di usaha rumahan krupuk cumi. Selain itu, tugas ketua juga mencari relasi pemasaran. Sementara itu, anggota lainnya berperan di bagian produksi untuk menghasilkan krupuk cumi. Rata-rata pekerja pada kelompok usaha tersebut berusia lanjut. Usaha ini merupakan usaha rumahan yang cukup dikenal, pasalnya krupuk cumi yang dihasilkan sudah dipasarkan ke beberapa wilayah tapal kuda (karesidenan besuki). Walaupun begitu, pemasaran krupuk cumi ini masih dibilang kurang luas. Hal tersebut dibuktikan dengan permintaan oleh beberapa peminat saja. Oleh karena itu, tim pengabdian akan membantu untuk memasarkan ke daerah yang lebih luas lagi khususnya di daerah luar tapal kuda.

Namun, permasalahan utamanya terletak pada kemasan dari krupuk cumi. Selama ini, di kelompok usaha rumahan Poklahsar Mandiri menggunakan kemasan polos dan tidak berlabel. Menurut peneliti sebelumnya, hal tersebut menjadi salah satu turunnya daya tarik masyarakat untuk membeli krupuk cumi ini (Willy \& Nurjanah, 2019). Keluhan ini dikarenakan tidak adanya mesin sablon kemasan plastik berlabel. Untuk menunjang kemasan plastik yang menarik perlu dibutuhkan proses printing pada plastik kemasan menggunakan alat sablon (Natadjaja, L., Cahyono, Y. B., and Yuwono, 2009).

Oleh karena itu, tim pengabdian melakukan survei awal yang berupa diskusi tentang hal tersebut. Poin utama dari hasil diskusi tersebut adalah alat sablon kemasan plastik. Mereka menginginkan adanya transfer teknologi yang berupa pembuatan alat sablon kemasan plastik krupuk cumi. Dengan permasalahan tersebut, tim pengabdian berinisiasi untuk memberikan kontribusi dalam bentuk perancangan dan pembuatan alat sablon kemasan plastik untuk krupuk cumi.

\section{METODE}

Tahapan yang dilakukan pada pelaksanaan kegiatan program pengabdian ini terbagi menjadi tiga bagian yang meliputi survei pendahuluan, pembuatan alat sablon kemasan, dan cara proses penyablonan pada kemasan plastik. Survei dilakukan untuk mengetahui secara nyata kondisi permasalahan terkini pada mitra Poklahsar Mandiri. Bentuk survei yaitu diskusi kecil yang menampung masukan dan masalah utama pada kelompok usaha ini. Masalah utama dari kelompok ini adalah tidak adanya alat sablon kemasan plastik.

Masalah utama tersebut dapat diatasi dengan pembuatan alat sablon kemasan plastik.
Alat ini dirancang dengan kapasitas pengisian kerupuk cumi di dalam kemasan plastik berkisar 100 gram. Konstruksi mesin sablon kemasan plastik terdiri dari beberapa komponen yaitu rangka alat sablon, list penjepit, frame screen, dan engsel. Setelah alat sablon dibuat, tim pengabdian memberikan pelatihan kepada para pekerja tentang cara penggunaan alat sablon tersebut. Secara umum, proses penyablonan kemasan plastik terbagi menjadi tiga langkah utama yaitu pembuatan film atau logo gambar, mengafdruk dan menyaput seperti ditunjukkan oleh Gambar 1.

\section{Membuat film / pola gambar}

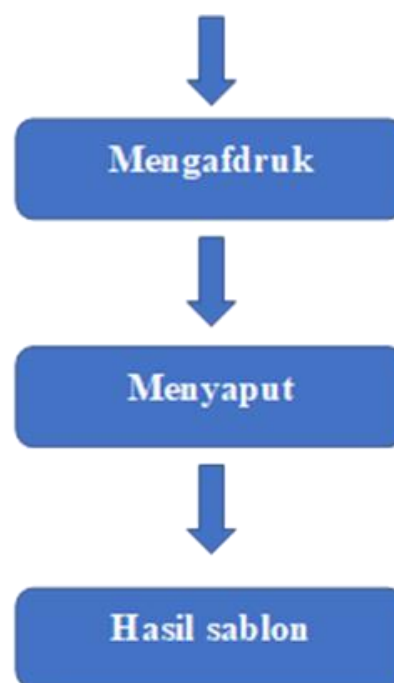

Gambar 1. Tahapan cara penyablonan kemasan plastik

\section{HASIL DAN PEMBAHASAN \\ Pembuatan Logo Kemasan dan Alat Sablon}

Alat sablon beserta dudukannya yang terbuat dari kayu telah dibuat. Alat sablon ini memakai screen mesh T150. Alat ini dapat memproduksi kurang lebih 30 - 35 lembar plastik sablon per jam sesuai dengan logo cetakannya. Gambar 2 merupakan logo atau desain kemasan plastik yang diafdruk dalam screen mesh atau saringan sablon (Nusantara, G., \& Graf, 2005). Sementara itu, Gambar 3 merupakan alat sablon yang telah didesain beserta dengan meja duduknya. Pada gambar tersebut terlihat bahwa desain kemasan plastik sudah diplot ke saringan sablon T150. Plot atau pengafdrukan desain kemasan plastik merupakan salah satu cara untuk membuat cetakan pada screen atau saringan sablon (Cahyadi \& Lanta L., 2019).

Untuk memperoleh resolusi gambar yang baik, desain logo kemasan plastik dibuat menggunakan software Corel Draw (Cholil, S. 
R., Hidayati, N., and Khoirudin, 2020). Gambar yang disediakan berupa ikan cumi dan outline border bunga. Hasil desain logo kemasan dari Corel Draw ditunjukkan oleh Gambar 2 yang mengindikasikan bahwa tampilan logo terlihat cukup jelas. Sementara itu, alat sablon dirancang secara sederhana seperti yang ditunjukkan oleh Gambar 3. Terlihat pada gambar tersebut bahwa rancang bangun alat sablon terdiri dari dudukan yang berupa kayu. $\mathrm{Di}$ atas kayu terdapat screen mesh T150 yang berukuran $30 \mathrm{~cm} \times 40 \mathrm{~cm}$. Dudukan dan screen mesh dihubungkan dengan 2 penjepit pada bagian ujungnya. Pembuatan alat sablon sederhana ini diharapkan dapat meminimalisir ongkos produksi serta meningkatkan penjualan kerupuk cumi.

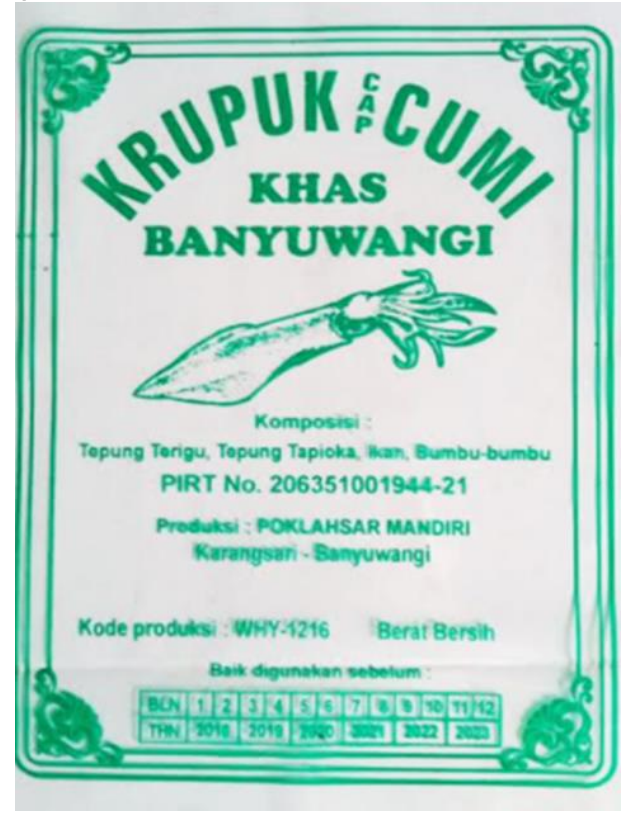

Gambar 2. Desain logo kemasan plastik sablon

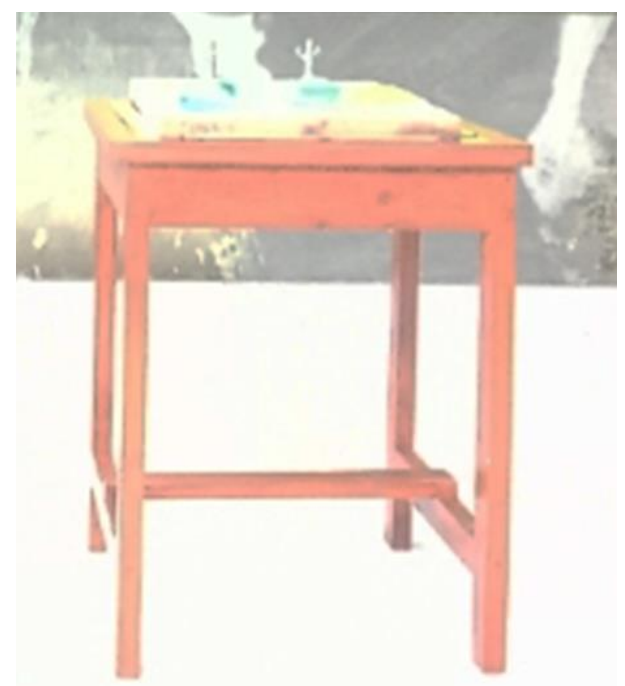

Gambar 3. Alat sablon beserta dudukannya Penyerahan Alat Sablon dan Pelatihannya

Pada hari Minggu 4 Oktober 2020, tim pengabdian melakukan perjalanan menuju tempat pengabdian yaitu Desa Karangsari, Kecamatan Sempu, Kabupaten Banyuwangi. Tim pengabdian ini melakukan beberapa agenda diantaranya penyerahan alat sablon dan press plastik (hand sealer). Selain itu, para pekerja juga diberikan pelatihan cara penggunaan alat sablon dan perawatannya. Gambar 4 menunjukkan penyerahan alat sablon ke mitra pengabdian. Proses penyerahan alat sablon ini diserahkan oleh ketua pengabdian kepada ketua Poklahsar Mandiri

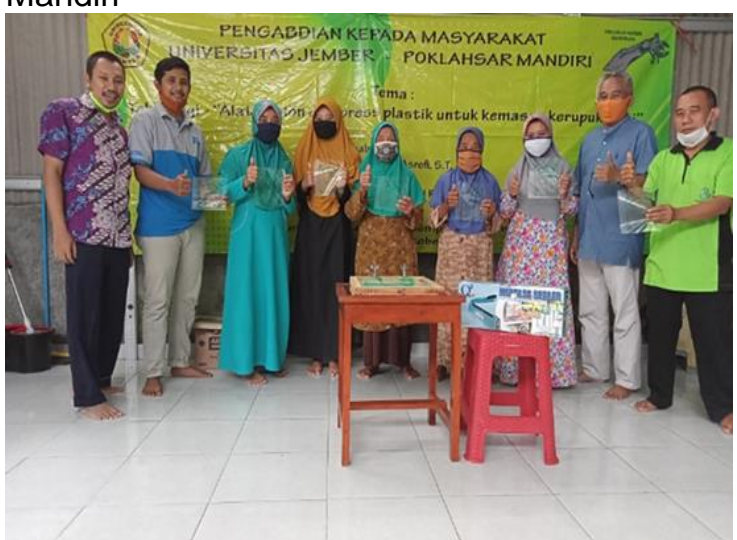

Gambar 4. Penyerahan alat sablon dan mesin press ke mitra pengabdian

Setelah penyerahan alat, kegiatan selanjutanya yaitu memberikan pelatihan tentang bagaimana penggunaan alat sablon. Gambar 5 menunjukkan dokumentasi pelatihan cara penggunaan alat sablon pada kemasan plastik dengan salah satu pekerja Poklahsar Mandiri.

Gambar 5(a) menunjukkan tim pengabdian memberikan pengetahuan dan pengarahan tentang cara penggunaan alat sablon kepada pekerja. Pada sesi ini tim pengabdian menjelaskan mengenai pencampuran cat sablon, jenis plastik yang disablon, cara menyablon dan juga membersihkan cat sablon dari screen.

Setelah sesi tersebut, pekerja langsung melakukan praktek menyablon pada alat sabon dengan logo yang sudah dibuat seperti pada Gambar 5(b). Akan tetapi, masih terdapat beberapa kendala dalam pelatihan menyablon ini terutama ruangan untuk proses penyablonan masih terbuka. Ruangan yang terbuka menyebabkan cat sablon mudah kering dan membuat aliran cat ke plastik menjadi buntu. Oleh karena itu, proses penyablonan harus diruangan yang minim udara. 


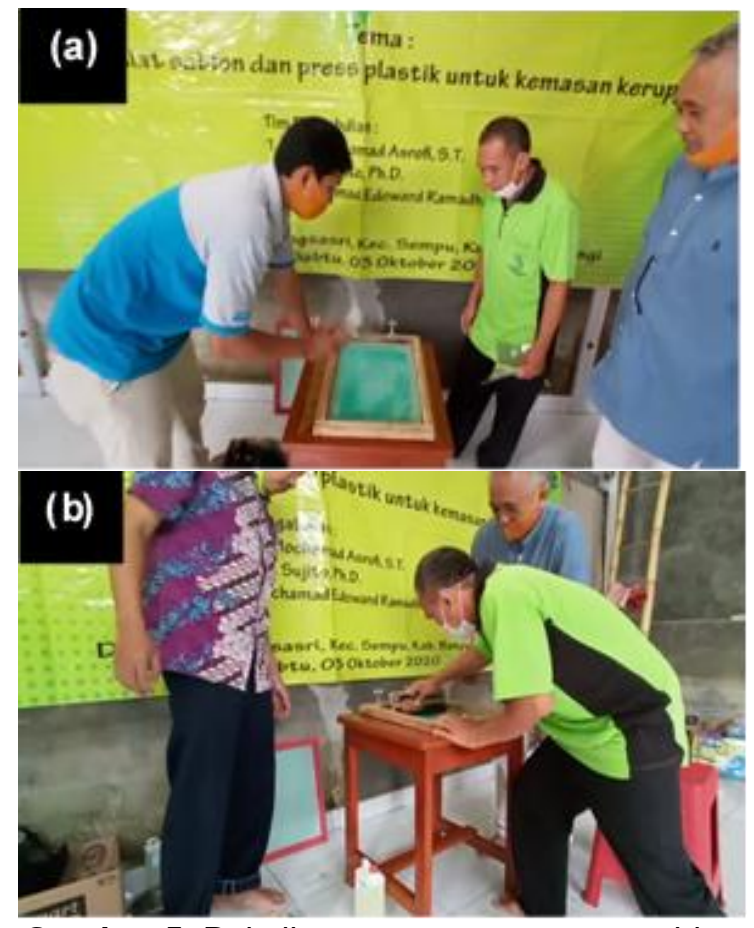

Gambar 5. Pelatihan cara penggunaan sablon dengan salah satu karyawan: (a) penjelasan dan (b) prektek menyablon

\section{SIMPULAN DAN SARAN}

Alat sablon untuk kemasan plastik sudah berhasil dibuat secara sederhana menggunakan beberapa komponen diantaranya dudukan kayu, screen sablon ukuran $30 \mathrm{~cm} \times 40 \mathrm{~cm}$ (mesh T150), dua penjepit dan rakel sablon. Selain itu, bahan lain yang diperlukan untuk proses penyablonan adalah cat sablon, pengencer M4, pembersih M3 atau tiner serta plastik kemasan. Penyerahan alat sablon dan alat press plastik diberikan langsung oleh ketua tim pengabdian kepada mitra pengabdian. Setelah penyerahan, tim pengabdian memberikan pengarahan dan pelatihan tentang cara penggunaan alat sablon beserta perawatannya. Tim pengabdian berharap bahwa dengan adanya alat sablon dan press plastik ini dapat meminimalisir ongkos produksi dan meningkatkan penjualan kerupuk cumi.

\section{UCAPAN TERIMAKASIH}

Tim pengabdian mengucapkan terima kasih atas bantuan dana pengabdian melalui hibah pengabdian pemula Universitas Jember tahun 2020 dengan nomor kontrak: 2662/UN25.3.2/PM/2020. Selain itu, ucapan terima kasih juga disampaikan kepada pihak yang terlibat dalam kegiatan pengabdian masyarakat terutama kelompok usaha POKLAHSAR Mandiri Banyuwangi.

\section{DAFTAR RUJUKAN}

Cahyadi, D., \& Lanta L., L. L. (2019). Pengembangan Cetak Kemasan Melalui Keterampilan Cetak Sablon. TANRA: Jurnal Desain Komunikasi Visual Fakultas Seni Dan Desain Universitas Negeri Makassar.

Cholil, S. R., Hidayati, N., and Khoirudin, K. (2020). Peningkatan Kemampuan Membuat Desain Grafis dengan Corel Draw Pada Siswa Ma Al-Wathoniyyah Semarang. Tematik, 1(1), 1-5.

Natadjaja, L., Cahyono, Y. B., and Yuwono, E. C. (2009). Kondisi Desain Kemasan Produk Makanan Ringan dan Minuman Instant pada Industri Kecil Skala Rumah Tangga (micro industry) di Kabupaten Kediri. Nirmana, 11(2), 93-105. https://doi.org/https://doi.org/10.9744/nir mana.11.2.pp.\%2093-105.

Nusantara, G., \& Graf, A. M. (2005). Panduan Praktis Cetak Sablon. Kawan Pustaka.

Willy, W., \& Nurjanah, S. (2019). PENGARUH

KEMASAN PRODUK DAN RASA
TERHADAP MINAT BELI YANG
BERDAMPAK PADA KEPUTUSAN
PEMBELIAN PELANGGAN MINUMAN
ENERGI. Jurnal IImu Manajemen.
https://doi.org/10.32502/jimn.v8i2.1820

